\title{
PERANCANGAN CUSTOMER KNOWLEDGE MANAGEMENT PADA PT PANDAWA MAJU PERKASA
}

\author{
Joni Suhartono; Caleb Kosashi \\ School of Information System, BINUS University \\ Jln. K.H. Syahdan No.9, Palmerah, Jakarta Barat 11480 \\ Jonis@binus.edu
}

\begin{abstract}
In the era of global trade, more countries want a quality of product with optimal price. PT Pandawa Maju Perkasa engaged in export trade services requires an application that can bridge the communication between the customer and the company. It can also create appropriate knowledge to present the product to the customer. Knowledge of the product obtained will be shared to the customer as company's marketing activities. In addition, critics and suggestions are very necessary for the improvement of customer service of the company. Research in this study was done by analyzing business process, designing model of knowledge management system, and designing system model. The design of the system made consisted of making class diagrams, use case diagrams, sequence diagrams, and user interface. The design of the CKM system will help the company capture customer demand for the goods they want, the communication between the customer and the company can be well established, critics and suggestions facility made is used to improve services to customers.
\end{abstract}

Keywords: customer, knowledge, management

\begin{abstract}
ABSTRAK
Pada era perdagangan global ini makin banyak negara menginginkan produk yang berkualitas dengan harga yang optimal. PT Pandawa Maju Perkasa yang bergerak dalam bidang jasa perdagangan ekspor membutuhkan aplikasi yang dapat menjembatani komunikasi antara customer dengan perusahaan dan membentuk suatu knowledge untuk menyajikan produk yang sesuai customer. Knowledge produk yang diperoleh nantinya akan dibagi ke customer sebagai kegiatan pemasaran perusahaan. Selain itu kritik dan saran customer sangat diperlukan untuk peningkatan pelayanan perusahaan. Metode yang digunakan pada penelitian ini adalah dengan melakukan analisis proses bisnis, merancang model manajemen pengetahuan, dan merancang model sistem. Rancangan system yang dibuat meliputi pembuatan class diagram, use case diagram, sequence diagram, dan user interface. Perancangan sistem CKM ini akan membantu perusahaan dalam menangkap kebutuhan pelanggan terhadap barang yang mereka inginkan, komunikasi antarpelanggan dengan perusahaan bisa terjalin baik, fasilitas kritik dan saran yang dibuat digunakan untuk peningkatan pelayanan ke pelanggan.
\end{abstract}

Kata kunci: customer, knowledge, management 


\section{PENDAHULUAN}

Dengan teknologi saat ini, konsumen dengan mudah dapat mencari informasi tentang produk di dunia maya. Akan tetapi, sering kali data yang ada bersifat random, yang akhirnya bisa membuat konsumen menjadi bingung dalam mencerna informasi tersebut. Pelanggan sangat membutuhkan informasi mengenai produk agar mereka bisa mengerti dengan jelas detail produk yang mereka inginkan.

PT PMP (Pandawa Maju Perkasa) merupakan perusahaan pengekspor barang dengan tujuan Eropa dan Timur Tengah. Perusahaan memandang kebutuhan pelanggan terhadap produk bisa diperoleh dari beberapa komunikasi yang disampaikan pelanggan. Kebutuhan pelanggan akan product information \& knowledge yang sangat dibutuhkan merupakan suatu peluang. Lebih lanjut, hal ini diharapkan bisa menjadi salah satu alat dalam menunjang strategi bisnis mereka dalam jangka panjang. PT Pandawa Maju Perkasa melihat pembentukan akan komunitas serta memiliki database konsumen maupun pemasok akan menunjang bisnis trading perusahaan.

Perancangan Customer Knowledge Management pada PT Pandawa Maju Perkasa dalam penelitian ini mencakup ruang lingkup sebagai berikut. Pertama, menyediakan informasi dan pengetahuan terhadap produk mempermudah user mencari; membagi serta membandingkan informasi dan pengetahuan produk yang dibutuhkan dengan berdasarkan kategori produk, serta informasiinformasi yang akan disediakan, dibuat sesuai dengan kebutuhan perusahaan dan hasil survei. Kedua, sebagai wadah bagi user untuk berbagi pengetahuan/informasi dari suatu produk. Ketiga, perancangan CKM model pada Marketing Process dan Service Process, bagian Campaign Management, Complain Management, dan Service Management yang didukung oleh aspek content, competence, collaboration, dan composition.

Perancangan Knowledge Management pada PT Pandawa Maju Perkasa memiliki tujuan sebagai berikut. Pertama sebagai analisis proses bisnis yang berjalan dalam perusahaan. Kedua, membuat sebuah aplikasi yang dapat menjembatani komunikasi antara customer dengan customer dan customer dangan perusahaan yang berupa knowledge suatu produk. Ketiga, membuat aplikasi website CKM untuk menampung masukan kritik dan keluhan dari customer. Adapun manfaat dari penelitian ini adalah (1) dapat menjadikan ide, kritik, dan saran customer sebagai masukan terhadap peningkatan pelayanan, (2) adanya sarana untuk berdiskusi atau berkomunikasi akan membentuk budaya sharing knowledge para pengguna website, (3) dapat menjadi sarana komunikasi dan berbagi knowledge dengan customer, (4) mempermudah dalam pengelolaan complain, (5) mempermudah proses pemasaran akan suatu produk.

Masalah yang dihadapi oleh perusahaan adalah sebagai berikut. Pertama, kesulitan dalam menentukan produk apa yang sangat dibutuhkan pelanggan. Kedua, complain pelanggan saat ini tidak ditangani serius sehingga pelanggan merasa kecewa terhadap pelayanan yang dibuat perusahaan. Ketiga, komunikasi dengan pelanggan tidak terdokumentasi dengan baik.

\section{METODE}

Dalam menyelesaikan masalah yang dihadapi, penelitian melakukan beberapa tahapan. Tahap pertama adalah analisis proses bisnis berjalan. Tahap kedua membuat arsitektur CKM. Tahap ketiga merancang model sistem seperti pembuatan class diagram, use case diagram, sequence diagram, dan perancangan layar. 


\section{Tinjauan Pustaka}

\section{Knowledge Management}

Knowledge Management (KM) adalah sebuah koordinasi sitematis dalam sebuah organisasi yang mengatur sumber daya manusia, teknologi, proses, dan struktur organisasi dalam rangka meningkatkan value melalui penggunaan ulang dan inovasi (Dalkir, 2011). Koordinasi ini bisa dicapai melalui menciptakan, membagi, dan mengaplikasikan pengetahuan dengan menggunakan pengalaman dan tindakan yang telah diambil perusahaan demi kelangsungan pembelajaran organisasi (continued organizational learning).

Karakteristik berbagai aktivitas manajemen pengetahuan menurut Tannebaum (Nawawi, 2012) ialah (a) pengembangan database organisasi mengenai pelanggaran, masalah yang bersifat umum dan serta pemecahannya; (b) mengenali para ahli internal, memperjelas apa yang mereka ketahui, dan mengembangkan kamus yang menjelaskan sumber daya internal kunci dan mengenali bagaimana menemukannya; (c) mendapatkan dan menangkap pengetahuan dari pada ahli tersebut untuk disebarkan kepada yang lain; (d) mendesain struktur pengetahuan yang membantu mengelola informasi dalam suatu cara yang dapat diakses dan siap untuk diaplikasikan; (e) menciptakan forum bagi orang yang ada di dalam perusahaan untuk berbagi pengalaman dan ide, baik dalam bentuk tatap muka, berkomunikasi melalui internet, website, chating room, e-mail, dan lain-lain; (f) memanfaatkan groupware sehingga memungkinkan berbagai macam orang di lokasi yang berbeda dapat berkomunikasi untuk menyelesaikan masalah secara bersama-sama dan mencatat informasi di dalam suatu domain pengetahuan yang telah dipilih; (g) bertindak untuk mengenali, mempertahankan talenta orang-orang yang memiliki pengetahuan yang diperlukan di dalam bidang kegiatan utama bisnis; (h) mendesain pelatihan dan aktivitas pengembangan lainnya untuk menilai dan mengembangkan pengetahuan internal; (i) menerapkan praktik penghargaan pengakuan dan promosi yang mendorong berlangsungnya kegiatan berbagi informasi antaranggota maupun antarunit dalam organisasi; (j) membantu pekerjaan serta menyediakan alat-alat yang mendukung kinerja, sehingga memungkinkan setiap orang menilai dan menerapkan pengetahuan apabila diperlukan; (k) memaknai database pelanggan, produk, transaksi, atau hasil dengan mengenali kecenderungan dan menggali informasi sebanyak mungkin; (l) mengukur modal intelektual di dalam upaya mengelola pengetahuan yang lebih baik; (m) menangkap dan menganalisis informasi yang terkait dengan perhatian pelanggaran, pilihanpilihan, dan kebutuhan dari lapangan, front line atau personel bagian pelayanan didorong untuk mampu memahami dengan lebih baik terhadap kecenderungan pelanggaran.

Tipe knowledge dalam organisasi menurut (Widayana, 2005) ialah tacit knowledge, explicit knowledge, dan implicit knowledge. Tacit knowledge adalah knowledge yang sebagian besar berada dalam organisasi. Tacit knowledge adalah sesuatu yang diketahui dan dialami namun sulit untuk diungkapkan secara jelas dan lengkap. Tacit knowledge sangat sulit untuk dipindahkan kepada orang lain karena knowledge tersebut tersimpan pada masing-masing pikiran (otak) para individu dalam organisasi sesuai dengan kompetensinya. Kemudian, explicit knowledge adalah pengetahuan dan pengalaman tentang 'bagaimana untuk', yang diuraikan secara lugas dan sistematis. Contoh konkretnya, yakni sebuah buku petunjuk pengoperasian sebuah mesin atau penjelasan yang diberikan oleh seorang instruktur dalam sebuah program pelatihan. Sedangkan implicit knowledge adalah knowledge yang tidak tampak, berada di antara tacit dan explicit kmowledge. Dinegara-negara yang sudah mengelola knowledge menjadi suatu aset, metode story telling (pengungkapan knowledge dengan cara cerita) merupakan salah satu cara efektif untuk mengubah implicit knowledge menjadi explicit knowledge. Tabel 1 menunjukkan sifat-sifat knowledge dalam perusahaan. 
Tabel 1 Sifat-sifat knowledge dalam perusahaan

Sumber: (Widayana, 2005)

\begin{tabular}{ccc}
\hline Klasifikasi knowledge & $\begin{array}{c}\text { Mudah } \\
\text { dikomunikasikan? }\end{array}$ & Terdokumentasi? \\
\hline Tacit & Tidak & Tidak \\
Explicit & Ya & Ya \\
Implicit(tersembunyi) & Ya & Tidak \\
Premium & Tidak & Ya \\
\hline
\end{tabular}

Lebih lanjut, Knowledge Management bertujuan untuk (a) mempermudah transisi karyawan lama yang berhenti (atau pensiun) yang digantikan oleh karyawan baru; (b) meminimalkan terjadinya kehilangan pengetahuan yang dialami perusahaan akibat karyawan berhenti; (c) identifikasi sumber daya dan pengetahuan penting yang dimiliki oleh perusahaan; (d) membangun sebuah toolkit yang dapat digunakan oleh individu, kelompok, dan organisasi untuk mengurangi kehilangan modal intelektual yang potensial (Dalkir, 2011). Menurut (Ronald, 2007), KM bertujuan untuk meningkatkan penciptaan, perolehan, identifikasi, validasi, evaluasi, konversi, pengaturan, penyimpanan, pengembangan, pendistribusian, peleburan, sharing, presentasi, pengaplikasian pengetahuan dengan cara yang sistematis.

Kemudian menurut (Nawawi, 2012), keuntungan/manfaat dari manajemen pengetahuan (KM) dalam organisasi adalah untuk meningkatkan kualitas pengambilan keputusan, meningkatkan kualitas penanganan pelanggan, mempercepat respons terhadap isu bisnis yang penting, meningkatkan profit, mengurangi biaya, meningkatkan pangsa pasar, menciptakan peluang bisnis baru, dan menyempurnakan pengembangan produk baru, serta meningkatkan mutu produk dan layanan. Sementara menurut (Ronald, 2007), manfaat KM adalah untuk meningkatkan efisiensi knowledge creation melalui komunikasi masalah dan pencarian solusi dengan observasi bersama; untuk membantu pembagian, peleburan, dan pendistribusian pengetahuan; dan untuk membantu pencarian ahli yang memiliki tacit knowledge dalam organisasi.

Menurut (Sabherwal \& Becerra-Fernandez, 2010), hambatan dalam KM sebagai berikut. Organisasi gagal mengajak knowledge worker untuk berbagi pengetahuan demi keuntungan organisasi. User sistem informasi tradisional tidak diajak untuk berkontribusi secara aktif untuk membangun KM, namun didelegasikan kepada konsultan sistem informasi.

\section{Proses Penciptaan Knowledge}

Menurut Nawawi (2012) untuk mendukung proses aktivitas dan pengembangan sumber daya manusia di suatu organisasi yang merupakan perwujudan dari model socialization, externalization, combination, internalization (SECI) digunakan perangkat teknologi informasi yang ada di organisasi melalui empat cara konversi (Gambar 1).

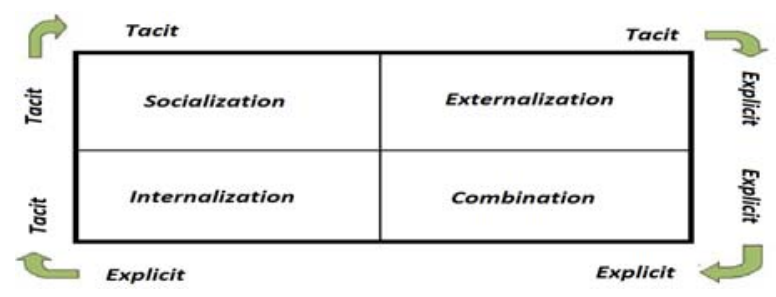

Gambar 1 SECI Model

Sumber: $\underline{w w w . a l l k m . c o m}$ 
Proses sosialisasi antarsumber daya manusia (SDM) di organisasi salah satunya dilakukan melalui pertemuan tatap muka (rapat, diskusi, dan pertemuan bulanan). Melalui pertemuan tatap muka ini, SDM dapat saling berbagi knowledge dan pengalamn yang dimilikinya sehingga tercipta knowledge baru bagi mereka. Hal ini baik untuk dilakukan karena bermanfaat untuk meningkatkan koordinasi, mempercepat proses akivitas, dan menumbuhkn budaya belajar. Porses sosialisasi juga dapat dilakukan melalui pendidikan dan pelatihan (training) dengan mengubah tacit knowledge para karyawan.

Sistem Knowledge Management akan sangat membantu proses eksternalisasi ini, yaitu proses untuk mengartikulasi tacit knowledge menjadi suatu konsep yang jelas. Dukungan terhadap proses eksternalisasi ini dapat diberikan dengan mendokumentasikan notulen rapat (bentuk eksplisit dari knowledge yang tercipta saat diadakannya pertemuan) ke dalam bentuk elektronik, untuk kemudian dapat dipublikasikan kepada mereka yang berkepentingan. Semua tacit knowledge yang diperoleh dari expert dan hasil pekerjaan expert yang antara lain berwujud konsep-konsep, sistem serta prosedur, manual, laporan pelaksanaan uraian pekerjaan, dan sebagainya harus didokumentasikan untuk kemudian dimanfaatkan oleh organisasi dalam menjalankan tugas pokok dan fungsinya.

Proses konversi knowledge melalui kombinasi adalah mengombinasikan berbagai explicit knowledge yang berbeda untuk disusun ke dalam system knowledge management. Media untuk proses ini dapat melalui intranet (forum diskusi), database organisasi dan internet untuk memperoleh sumber eksternal. Fitur-fitur enterprise portal, seperti knowledge organization system yang dimiliki fungsi untuk pengategorian informasi (taksonomi), pencarian, dan sebagainya sangat membantu dalam proses ini. Demikian pula content management yang memiliki fungsi untuk mengelola informasi organisasi, baik yang terstruktur (database) maupun yang tidak terstruktur (dokumen, laporan, notula) dapat mendukung proses kombinasi ini.

Semua dokumen data, informasi dan knowledge yang sudah didokumentasikan dapat dibaca oleh orang lain. Pada proses inilah terjadi peningkatan knowledge sumber daya manusia. Sumbersumber explicit knowledge dapat diperoleh melalui media intranet (database organisasi), surat edaran/surat keputusan, papan pengumuman dan intranet serta media massa sebagai sumber eksternal. Untuk dapat mendukung proses ini, system perlu memiliki alat bantu pencarian dan pengambilan dokumen.

\section{Internal vs External Knowledge}

Internal knowledge berasal dari sumber-sumber informasi di dalam sebuah organisasi, misalnya spesialis Electronic Data Processing (EDP). Sebaliknya, pengetahuan eksternal tersedia dari luar, misalnya dari internet atau dari ahli perusahaan lain. Akuisisi knowledge dari sumber eksternal sering menguntungkan karena tidak ada kebutuhan dalam perusahaan untuk proses jangka panjang, memakan waktu pengembangan pengetahuan. Dalam banyak kasus, penggunaan sumber-sumber pengetahuan eksternal merupakan suatu keharusan.Knowledge meningkat dengan pesat dan jumlah sumber informasi meningkat juga. Akhirnya, harus disebutkan bahwa pengetahuan internal dalam perusahaan dapat digunakan secara langsung, sementara pengetahuan eksternal tidak langsung tersedia, tetapi dapat menjadi keuntungan yang tinggi.

\section{Theoretical vs Practical Knowledge}

Knowledge praktis dapat dibagi menjadi dua aspek utama. Salah satunya adalah keterampilan yang diperlukan untuk mencapai tujuan dalam suatu situasi tertentu. Aspek kedua adalah berkaitan dengan keakraban karyawan dengan pekerjaan mereka. Sebaliknya, knowledge teoretis adalah sebuah karakter intelektual dan deskriptif yang termasuk teori, metode, dan fakta-fakta yang perlu tahu tentang pekerjaan. 


\section{Customer Knowledge Management}

Menurut (Wilde, 2011), CKM adalah tentang mendapatkan, berbagi dan memperluas pengetahuan yang berada di pelanggan, untuk kedua pelanggan dan keuntungan perusahaan.Tujuan dari CKM ini adalah untuk meningkatkan orientasi pelanggan dan untuk membangun hubungan pelanggan secara jangka panjang dan dapat memberi banyak keuntungan pada perusahaan.

Menurut (Wilde, 2011), CKM mempunyai fokus pada knowledge in-house seorang pelanggan. Akibatnya, pelanggan dan knowledge di dalamnya tidak cukup dan tanpa sistem yang terintegrasi ke dalam proses organisasi. Pelaksanaan CKM bermanfaat untuk mengisi kesenjangan ini. Jika pengetahuan pelanggan yang akan digunakan dengan cara yang berorientasi pada target, maka perlu membuatnya agar dapat diakses, untuk mengembangkan dan berbagi secara sistematis. Dengan mengintegrasikan CKM, para pelanggan dapat menjadi mitra pengetahuan aktif untuk perusahaan.

\section{Customer Knowledge Categories}

(Wilde, 2011) menerangkan bahwa integrasi pengetahuan pelanggan ke dalam kegiatan operasional masih relatif baru. Literatur yang relevan berbeda antara pengetahuan tentang pengetahuan, pelanggan dari pelanggan dan pengetahuan bagi pelanggan. Dibagi menjadi 3 (tiga) jenis. Knowledge about customer; tipe knowledge ini berorientasi pada informasi tentang pelanggan yang meliputi pembelian dan perilaku pembayaran, motivasinya, kebiasaan membeli dan permintaan. Bentuk knowledge ini diperoleh dengan cara pasif, yaitu hasil dari analisis, wawancara dan observasi yang dilakukan, misalnya, oleh lembaga riset pasar. Knowledge from customer; knowledge dari pelanggan sebagian besar diperoleh perusahaan dengan cara langsung. Pelanggan menginformasikan kepada perusahaan tentang pengalamannya dengan produk, jasa, proses atau harapannya. Juga interpretasi dari pasar atau customer knowledge pesaingnya atau teknologi sebagai usulan, baik untuk solusi yang termasuk kategori pengetahuan. Sehingga perusahaan dapat mengambil bagian aktif dalam menyimpan knowledge customer ini. Knowledge for customer; ketika pelanggan berbagi knowledge dengan perusahaan lain, perusahaan ini kemudian berada dalam posisi untuk mengidentifikasi kesenjangan knowledge yang mungkin dan untuk lebih mengembangkan 'non-knowledge' customer. Pelanggan harus didukung dengan knowledge for customer untuk mengungkap kekurangan knowledge. Contoh dari hal ini adalah informasi mengenai produk-produk seperti kualitas baik dan harga.

Tabel 3 menjelaskan perbedaan tipe knowledge berorientasi customer dan kekhususan masingmasing.

Tabel 3 Tabel Perbedaan Tipe Customer Knowledge

Sumber: (Wilde, 2011)

\begin{tabular}{|c|c|c|c|}
\hline & Knowledge about customer & Knowledge from customer & Knowledge for customer \\
\hline Company/person & $\begin{array}{l}\text { B2B: industri, kredit } \\
\text { B2C: umur, jenis kelamin, } \\
\text { pendapatan }\end{array}$ & $\begin{array}{l}\text { Pemilik tujuan, Strategi, } \\
\text { pemilik ekspektasi, } \\
\text { kepentingan }\end{array}$ & $\begin{array}{l}\text { Tentukan masalah dan } \\
\text { memastikan permintaan }\end{array}$ \\
\hline Product/service & $\begin{array}{l}\text { Produk portofolio, sejarah } \\
\text { pembelian, durasi kontrak }\end{array}$ & $\begin{array}{l}\text { Kekuatan / kelemahan } \\
\text { kualitas dibandingkan } \\
\text { dengan pesaing }\end{array}$ & $\begin{array}{l}\text { Lingkup penawaran, fitur } \\
\text { berkualitas, harga }\end{array}$ \\
\hline Actions of the company & $\begin{array}{l}\text { Jenis, intensitas, frekuensi } \\
\text { kegiatan disesuaikan }\end{array}$ & $\begin{array}{l}\text { Kekuatan / kelemahan } \\
\text { kegiatan dibandingkan } \\
\text { dengan pesaing }\end{array}$ & $\begin{array}{l}\text { Penawaran khusus, } \\
\text { keterampilan individu, kondisi } \\
\text { khusus }\end{array}$ \\
\hline $\begin{array}{l}\text { Reaction of the } \\
\text { customer }\end{array}$ & $\begin{array}{l}\text { pergantian, batas laba kotor, } \\
\text { customer lifetime value, } \\
\text { keluhan kepuasan pelanggan }\end{array}$ & $\begin{array}{l}\text { Wawasan dan niat } \\
\text { mengenai produk dan } \\
\text { layanan }\end{array}$ & $\begin{array}{l}\text { Meraih status pelanggan } \\
\text { (customer binding programs) } \\
\text { atau tahap diskon }\end{array}$ \\
\hline
\end{tabular}




\section{Model CKM}

Menurut (Sanayei \& Sadidi, 2011), model proses CKM memperkenalkan dua aspek yang menjelaskan tentang bagaimana knowledge itu tercipta, dimanfaatkan, dan digunakan di dalam organisasi. Sebagai konsekuensinya, model CKM memiliki sudut pandang jenis dan keberadaan knowledge. Sudut pandang keberadaan knowledge diwakilkan dengan dua aspek kolaborasi dan komposisi. Kolaborasi mempunyai keterkaitan dengan penciptaan dan pemanfaatan knowledge. Aspek komposisi knowledge juga berhubungan dengan pemanfaatan dan penggunaan knowledge di antara sejumlah besar individu. Komposisi knowledge utamanya adalah membantu orang-orang dalam menemukan knowledge explicit.

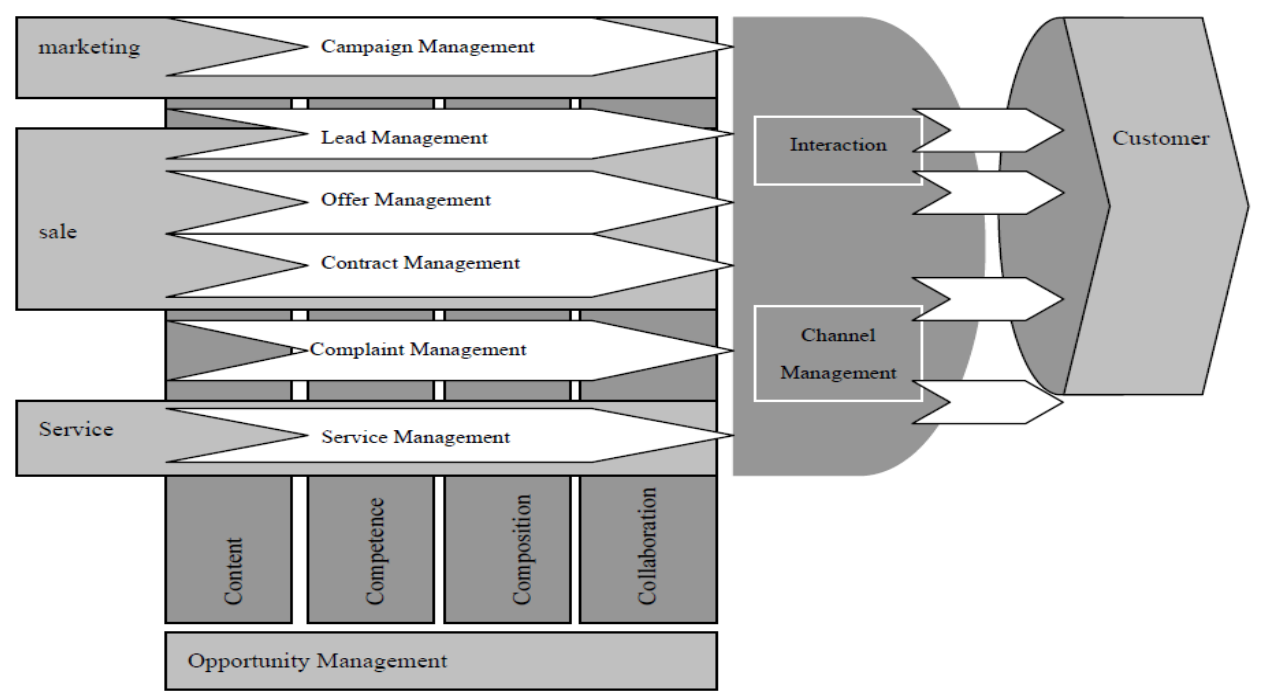

Gambar 2 Model CKM

Sumber: (Sanayei \& Sadidi, 2011)

Lebih lanjut, (Sanayei \& Sadidi, 2011) menjelaskan bahwa terdapat enam proses bisnis yang terkait dengan CKM. Campaign Management adalah inti dari proses pemasaran yang memenuhi ide interaktif, kontak individual yang berbeda dengan transaksi tradisional pemasar. Hal ini berhubungan dengan perencanaan, realisasi, pengaturan, dan pengawasan aktivitas pemasaran terhadap target. Tujuannya adalah menghasilkan kesempatan yang bernilai atau memberikan petunjuk sebagai dasar dari Lead Management. Lead management adalah konsodilasi, kualifikasi, dan pengutamaan kontak dengan calon customer. Tujuannya adalah memberikan pegawai penjualan sebuah daftar prioritas yang memenuhi syarat dan memiliki prospek dalam proses offer management. Offer management adalah inti dari proses penjualan. Tujuannya adalah konsistensi pembuatan dan pengiriman produk atau jasa perusahaan yang meluas pada individual dalam penawaran. Contract management adalah pembuatan dan pengendalian kontrak-kontrak untuk persediaan produk dan jasa. Tugasnya adalah mendukung proses offer management atau service management. Hal ini meliputi pengendalian dan pengaturan kontrak jangka panjang, seperti outsourcing atau asuransi. Complain management mengartikulasi ketidakpuasan customer yang telah diterima, diproses, dan dikomunikasikan pada perusahaan. Tujuannya adalah meningkatkan kepuasan customer dalam jangka pendek dengan pengarahan langsung pada masalah dan merancang proses peningkatan dalam jangka panjang. Service management adalah perencanaan, realisasi, dan pengaturan langkah-langkah penyediaan layanan sebuah output yang tidak bisa diukur oleh perusahaan dengan keterlibatan langsung dengan pelanggan. Contohnya melingkupi perawatan, perbaikan, dan pendukungan aktivitas tahap 'after-sales' serta pengadaan finansial atau jasa telekomunikasi setelah menyimpulkan kontrak. 
Kemudian (Sanayei \& Sadidi, 2011) menambahkan terdapat empat aspek dalam penyampaian jasa yang merupakan penopang subproses CKM. Empat aspek tersebut kadang memerlukan proses pendukung seperti pengaturan content atau information competencies dari penciptaan ke pengaplikasian dalam siklusnya. Aspek collaboration dan composition menyediakan infrastrukstur yang mendukung ketetapan knowledge ke suatu proses bisnis ketika tidak menjadi sebuah proses. Semua aspek knowledge perlu didukung oleh sistem informasi yang menyampaikan fungsi spesifik pada setiap aspeknya.

Content dari aspek memerlukan pemanfaatan dari content management atau sistem manajemen dokumen, aspek competence menggunakan direktori yang ahli seperti skill management. Aspek composition mempunyai kaitan utama dengan penggunaan sistem pencarian dan navigasi seperti knowledge mining system, personalization, taxonomy management system dan knowledge map. Sistem pendukung dalam sub-proses CRM digambarkan melalui model CKM. Model CKM juga digunakan untuk meningkatkan performa perusahaan dengan menggabungkan aspek dalam knowledge dan information support system.

\section{HASIL DAN PEMBAHASAN}

Dalam perkembangannya, sebagai perusahaan ekspor, PT Pandawa Maju Perkasa juga ingin menjadikan sebagai perusahaan "One Stop Solution” untuk menjembatani importir-importir dari luar negeri yang tertarik dengan produk yang ada di Indonesia.

\section{CKM Model}

Pada Gambar 3 terlihat CKM model, yang akan difokuskan di bagian fungsi Campaign Management, Complain Management, dan Service Management dengan membahas tentang informasi produk dan pemasok. Aspek knowledge yang digunakan adalah Content, Competence, Composition, dan Collaboration. Selain itu tipe Knowledge CKM model ini juga berfokus pada Knowledge from Customer. Pada hasil analisis wawancara dan simpulan strategi yang telah didapatkan, maka perusahaan membutuhkan suatu wadah yang mampu membentuk suatu komunitas untuk membagi informasi akan suatu produk dan pemasok. Wadah tersebut meningkatkan serta mengembangkan keakuratan data yang dimiliki oleh PT Pandawa Maju Perkasa.

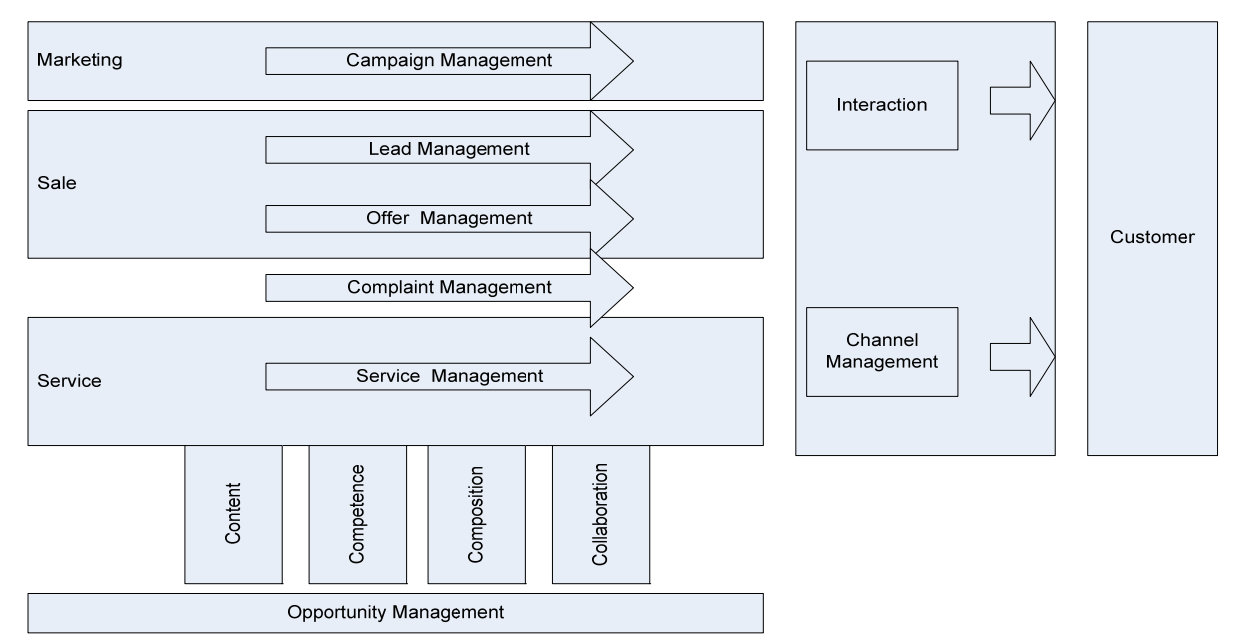

Gambar 3 CKM Model 
Campaign management yang akan dibahas adalah bagaimana cara membentuk dan mengembangkan suatu komunitas dalam suatu wadah website. Para anggota komunitas tersebut akan membagi pengetahuan mereka akan informasi suatu produk, seperti spesifikasi, harga, pemasok, dan juga komentar-komentar akan kebaikan ataupun kelemahan produk tersebut. Output yang dikeluarkan memang tidak dapat langsung diukur kegunaannya, tetapi di era perdagangan global ini dengan memiliki komunitas jelas akan memiliki keunggulan yang lebih dibanding dengan pesaing. Sedangkan untuk keadaan sekarang ini data, informasi dan pengetahuan akan suatu produk didapat oleh PT Pandawa Maju Perkasa terbatas hanya melalui informasi yang ada didapat dari pemilik, karyawankaryawan kantor, dan relasi bisnis dari pemilik. Oleh karena itu website CKM ini tentu akan sangat mtembantu PT Pandawa Maju Perkasa dalam mendapatkan dan mengembangkan informasi suatu produk. Kemudian, complain management yang akan dibahas adalah bagaimana cara menerima dan menjawab komplain dari customer. Pada website akan disediakan fitur-fitur untuk memberikan masukan berupa komplain atau kritik dan dari sisi admin diberikan fitur untuk menerima dan menjawab complain atau kritik tersebut. Lalu service management merupakan pengelolaan layanan dari berbagai keluhan pelanggan; dan perusahaan harus bisa mengatasi keluhan dan komplain dari pelanggan tersebut. Perusahaan saat ini belum mempunyai customer care yang melayani kritik dan saran dari pelanggan. Pelanggan yang ingin menyampaikan kritik dan saran dapat mendatangi PT Pandawa Maju Perkasa secara langsung. Hal tersebut dirasa masih kurang efektif dalam menanggapi keluhan dan merealisasikan ide dari pelanggan. Maka dari itu, dibutuhkan website CKM untuk mengisi kesenjangan ini.

Aspek Content yang akan disediakan adalah berdasarkan kebutuhan akan informasi yang dibutuhkan oleh komunitas. Pada website akan disediakan fitur-fitur bagi user untuk menambahkan dan memperbarui data produk seperti spesifikasi dan harga. User dapat memasukkan harga produk yang kemudian dapat dinilai (rate) oleh user lainnya yang menandakan keakuratan data tersebut. Pemasok (toko) user dapat memasukkan alamat beserta foto toko tempat produk tersebut tersedia untuk dibeli serta toko tersebut dapat dinilai (rate) oleh user yang menandakan bahwa toko memberikan pelayanan yang baik/memuaskan (good service). Selain itu juga, terdapat forum untuk berbagi komentar baik untuk kebaikan ataupun kelemahan dari produk tersebut yang dapat diberi komentar oleh user lainnya, sehingga terjadi diskusi yaitu pertukaran knowledge (knowledge sharing). Berita (news) perusahaan memberikan ide (share idea) dan memberitakan acara (event).

Dengan fokus pada content, maka website CKM ini menyediakan berbagai fitur di dalamnya untuk memenuhi tiga jenis user/customer knowledge tersebut. Terdapat fitur user profile, user control, most discussed product, dan request yang dapat digunakan untuk memperoleh knowledge about user/customer. Terdapat pula fitur forum, share idea(price, store), view idea, comment, dan suggestion yang dapat digunakan user/customer untuk memberikan knowledge pada perusahaan. Lalu ada fitur news and events, company profile, company information yang dapat digunakan perusahaan untuk memberikan knowledge for user/customer.

Aspek Competence yang akan disediakan adalah berupa e-learning, admin akan memasukkan e-manual book pada setiap item/produk bagi customer guna untuk mengetahui kelebihan dan kekurangan produk. Lalu aspek Composition; tipe perolehan customer knowledge pada tahap ini berasal dari informasi yang di-posting oleh user ke dalam kategori-kategori tertentu. Pengategorian ini digunakan untuk memudahkan user/customer dalam mencari knowledge mengenai harga, toko, dan komentar yang disampaikan user/customer lain. Hal ini juga akan mempermudah perusahaan dalam mengumpulkan data posting yang diberikan oleh user/customer yang kemudian dapat diolah oleh perusahaan untuk menjadi knowledge. Kemudian, aspek Collaboration membahas mengenai bagaimana hubungan antara customer dengan perusahaan, fitur yang akan disediakan adalah inbox yaitu digunakan oleh customer dan perusahaan untuk komunikasi. Customer dapat memberikan ide, kritik, saran, dan pertanyaan yang kemudian dibalas/dijawab oleh admin. 
Untuk pendistribusian knowledge dari user/customer dibutuhkan Interaction Management dan Channel Management. Interaction Management merupakan media berbasis komunikasi yang membantu memfasilitasi hubungan yang efektif antara perusahaan dengan pelanggan. Channel Management merupakan cara lain untuk menangani komunikasi di beberapa saluran untuk mendistribusikan knowledge mengenai jasa yang ditawarkan. Informasi yang dibutuhkan oleh user/customer pada channel management ini dilakukan melalui sebuah website. Channel Management dan Interaction Management saling berkaitan dengan Knowledge about Customer, Knowledge from Customer, dan Knowledge for Customer.

Customer Knowledge Categories dapat dijadikan landasan untuk pemetaan fitur website CKM pada perusahaan. Melalui kategori ini diharapkan website CKM mampu mempermudah perusahaan untuk mendapatkan knowledge tentang dan dari user/customer, juga mampu memberikan knowledge untuk user/customer. Perusahaan dapat menganalisis knowledge yang didapat dari customer atau knowledge tentang customer itu sendiri, serta perusahaan dapat memberikan knowledge tentang produk dan perusahaannya kepada customer. Berikut pemetaan fitur melalui jenis customer knowledge.

Pada kategori knowledge about customer adalah untuk tahu bagaimana customer dari perusahaan. Perolehan customer knowledge pada tahap ini berasal dari user yang telah mendaftar dengan mengisi form pendaftaran dan dapat diketahui dari fitur user profile, user control, most discussed product, dan request. Perusahaan dapat menganalisis dan menggabungkan data serta informasi menjadi knowledge about user/customer, user control \& most discussed product.

Pada jenis knowledge from customer, website dapat dijadikan wadah bagi user/customer untuk memberikan informasi dan knowledge untuk perusahaan maupun untuk sesama customer. Pada website terdapat bagian produk yang juga dapat diberikan komen yang sesama user/customer dapat saling bertukar informasi. Terdapat juga, bagian harga dan toko tempat user/customer dapat memberikan informasi mengenai harga produk serta toko yang menjual produk tersebut yang dapat dianalisa dan di proses oleh perusahaan menjadi knowledge.

Perusahaan tentu perlu untuk memberikan knowledge bagi user/customer, baik berupa product knowledge atau news and event dari perusahaan. Perusahaan memiliki fitur pada website berupa pengumuman atau news and event yang dapat memberikan informasi tentang aktivitas perusahaan. Tabel 4 menggambarkan pemetaan fitur knowledge.

Tabel 4 Pemetaan Fitur Knowledge

\begin{tabular}{lll}
\hline $\begin{array}{l}\text { Knowledge about the } \\
\text { Customer }\end{array}$ & $\begin{array}{l}\text { Knowledge from the } \\
\text { Customer }\end{array}$ & $\begin{array}{l}\text { Knowledge for the } \\
\text { Customer }\end{array}$ \\
\hline User control & Forum & News and Events \\
User profile & Share Idea & Company profile \\
Most discussed topic & - Price & Company information \\
Request & - Store & Status Idea \\
& Comment & \\
\hline
\end{tabular}




\section{Rancangan Sistem yang Dibangun}

\section{Use Case Diagram}

Pada use case diagram (Gambar 4) digambarkan bagaimana aktor sistem berhubungan dengan system CKM melalui beberapa modul seperti comment, create price, question, rate store, request item, news.

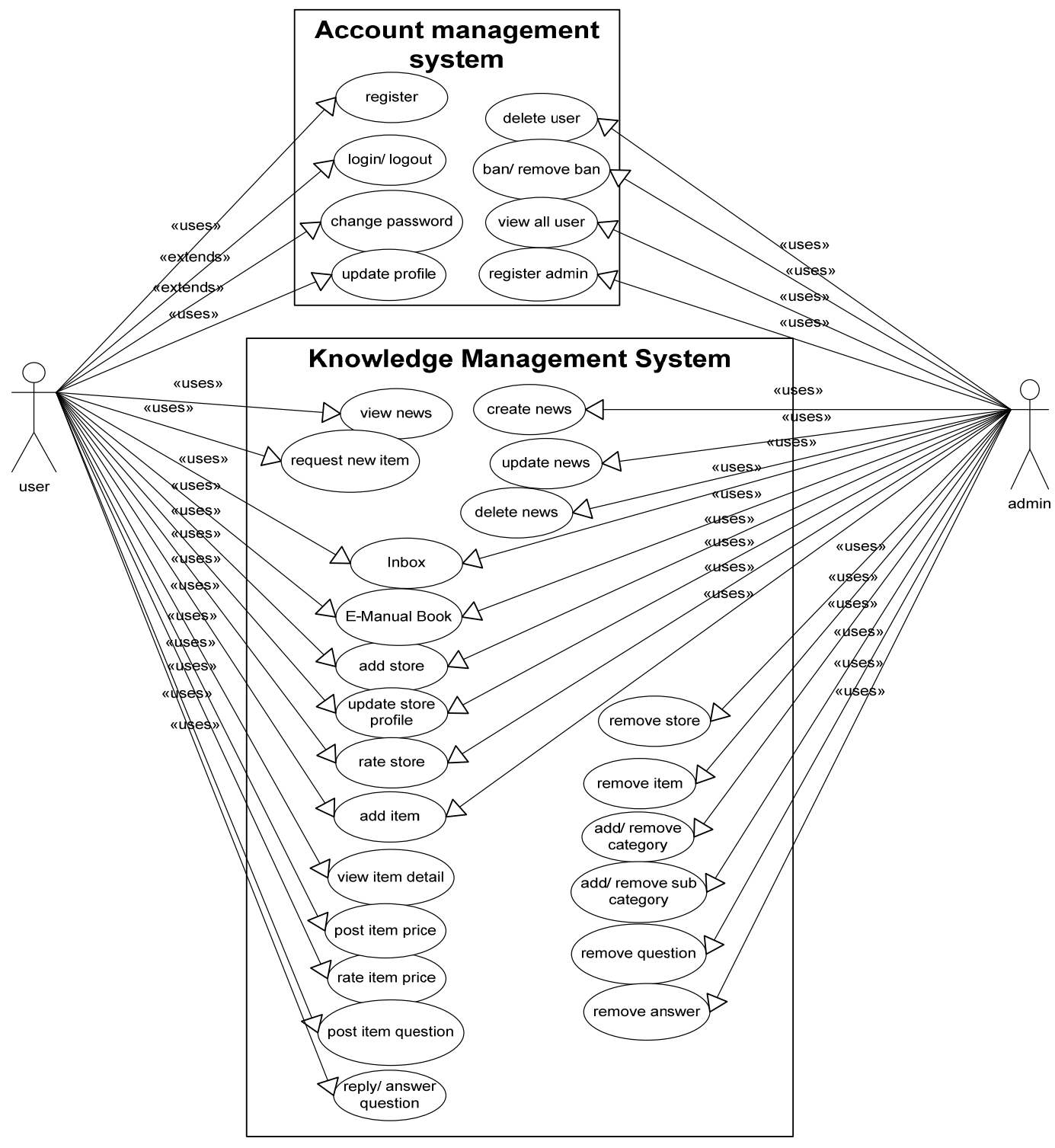

Gambar 4 Use Case Diagram Knowledge Management System

\section{Class Diagram}

Gambar 5 merupakan Class Diagram untuk perancangan KM pada perusahaan yang menggambarkan hubungan antar objek dalam aplikasi KM yang akan dibangun. 


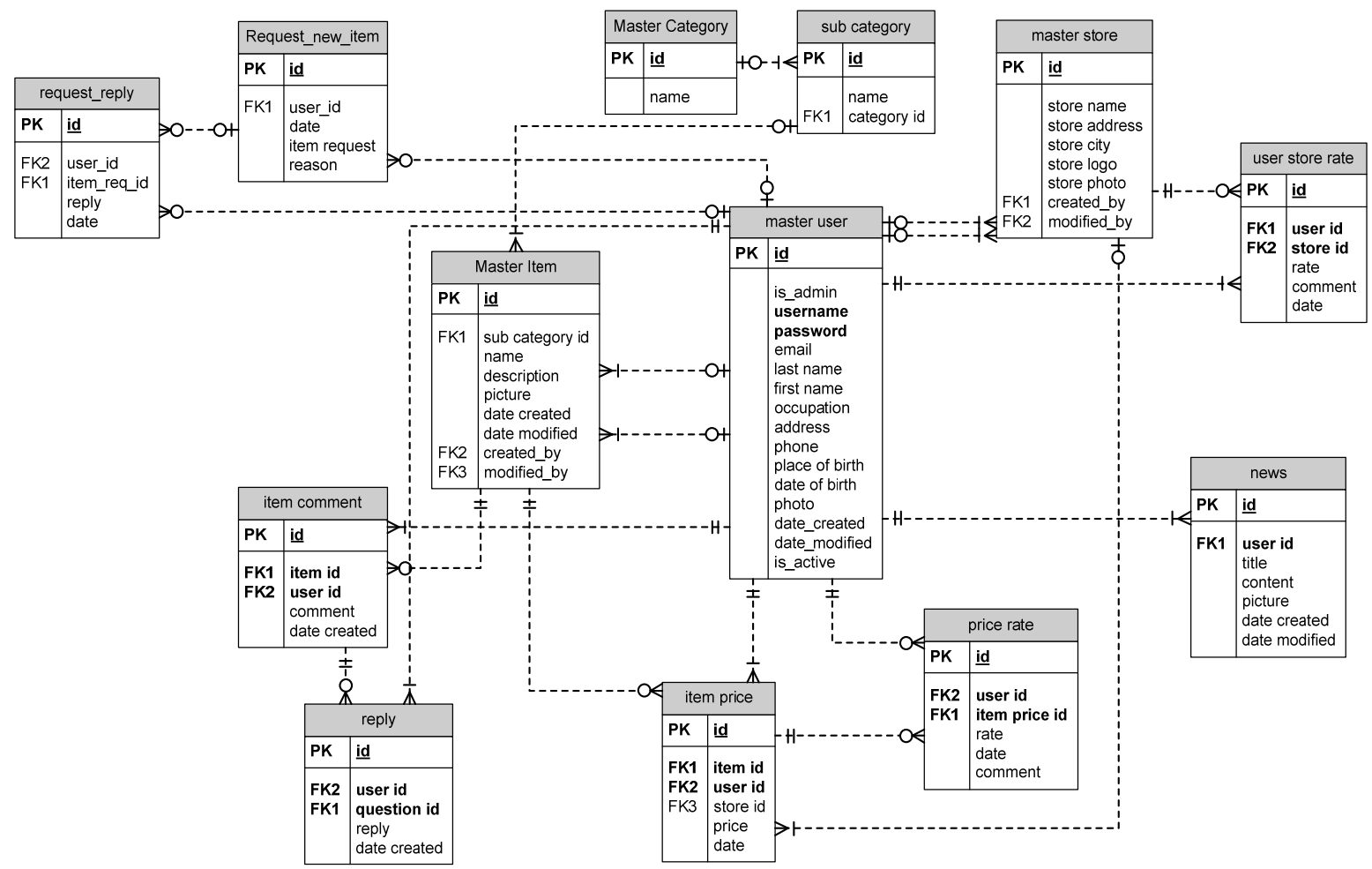

Gambar 5 Class Diagram

Gambaran sequence diagram dari System Knowledge Management ditunjukkan pada Gambar 6, Gambar 7, dan Gambar 8. Sequence diagram rate store (Gambar 6) digunakan untuk membuat data dari suatu store. Sementara Gambar 7 menunjukkan proses pembuatan kommentar dari pelanggan. Lalu Gambar 8 menunjukkan bagaimana staf akan me-reply suatu request dari pelanggan. Sistem akan membaca class request sesuai request yang akan di-reply oleh staf. Kemudian setelah staf menekan tombol SAVE, selanjutnya data akan disimpan pada class Request.

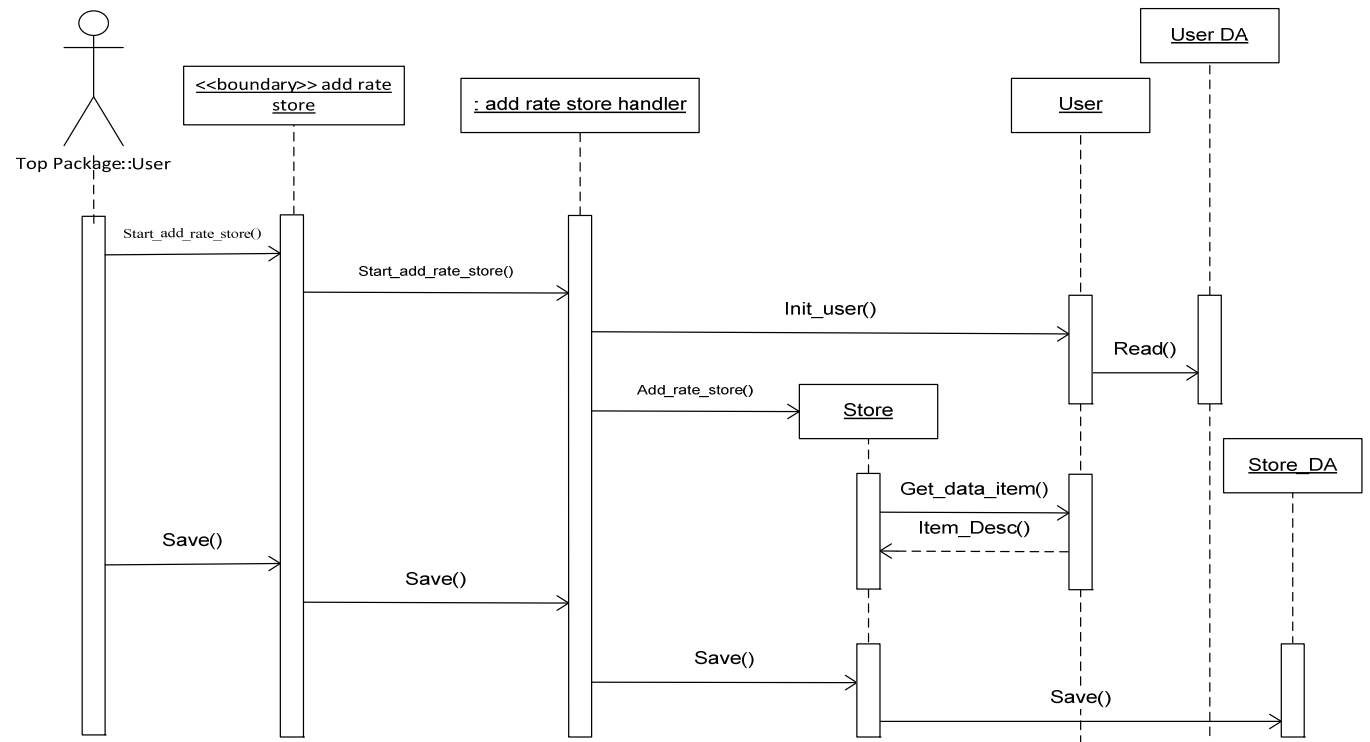

Gambar 6 DA Sequence Diagram New Store 


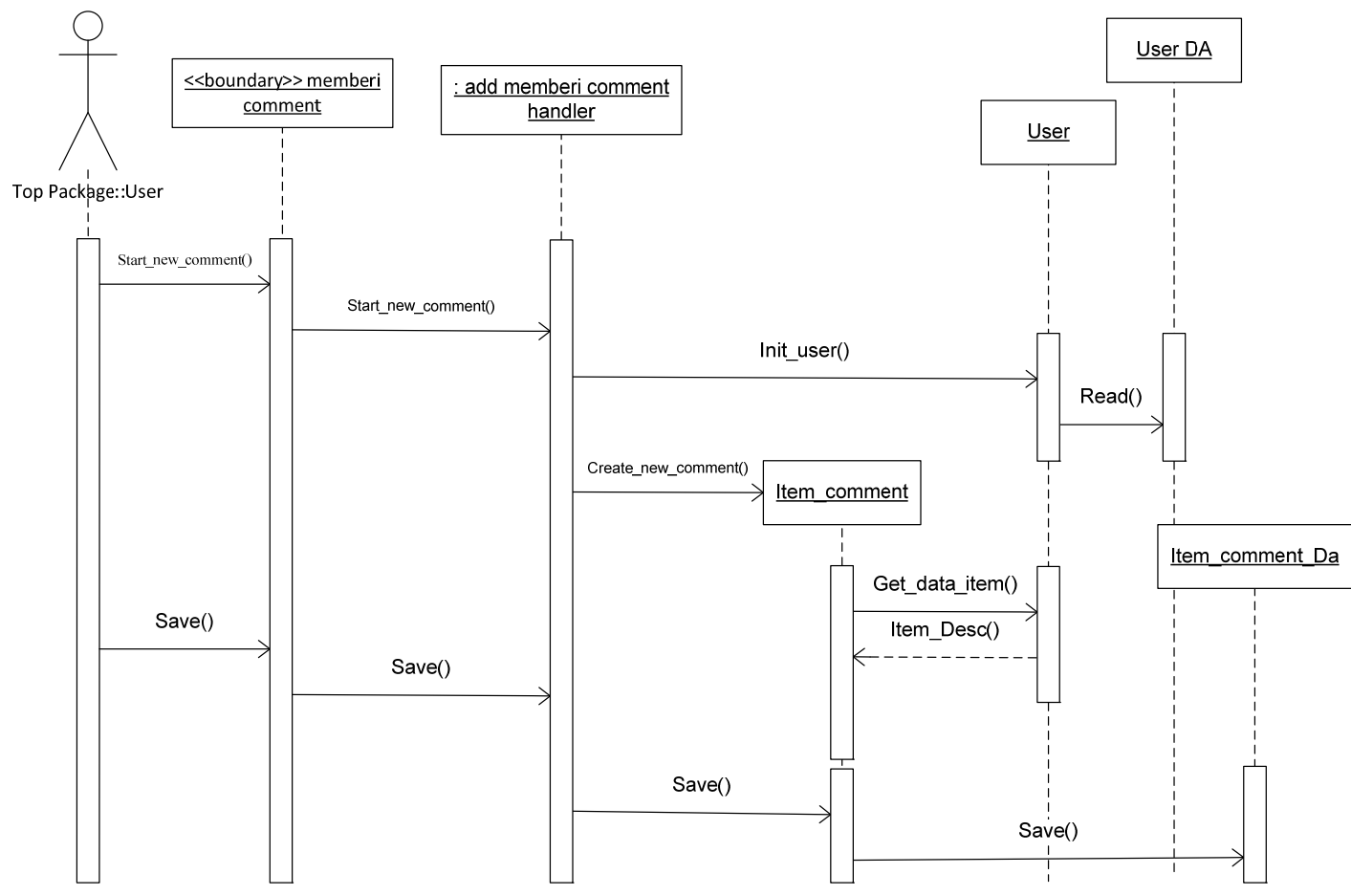

Gambar 7 DA Sequence Diagram Memberi Komentar

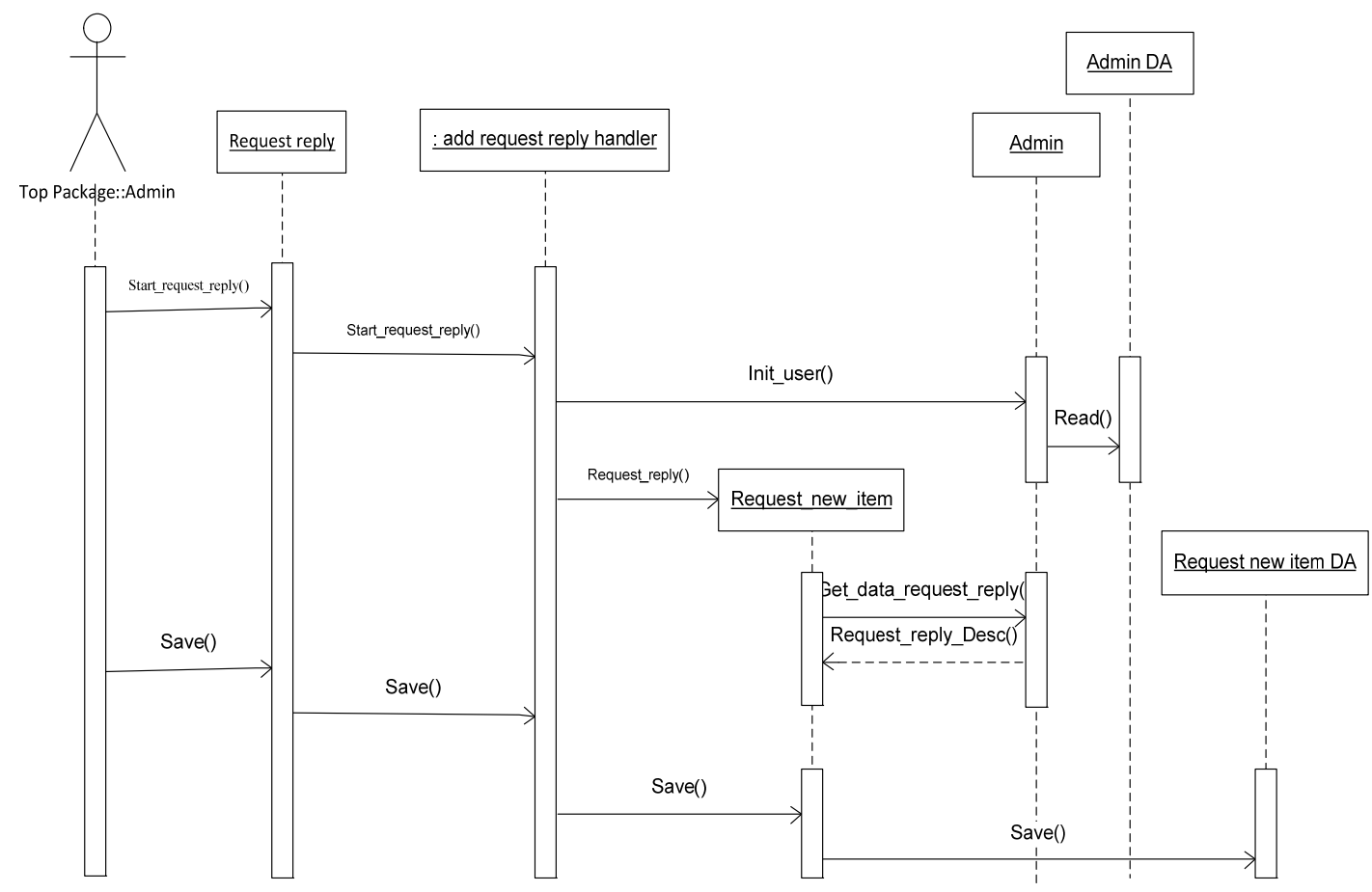

Gambar 8 DA Sequence Diagram request reply 


\section{Package Diagram}

Gambar 9 merupakan Package Diagram.

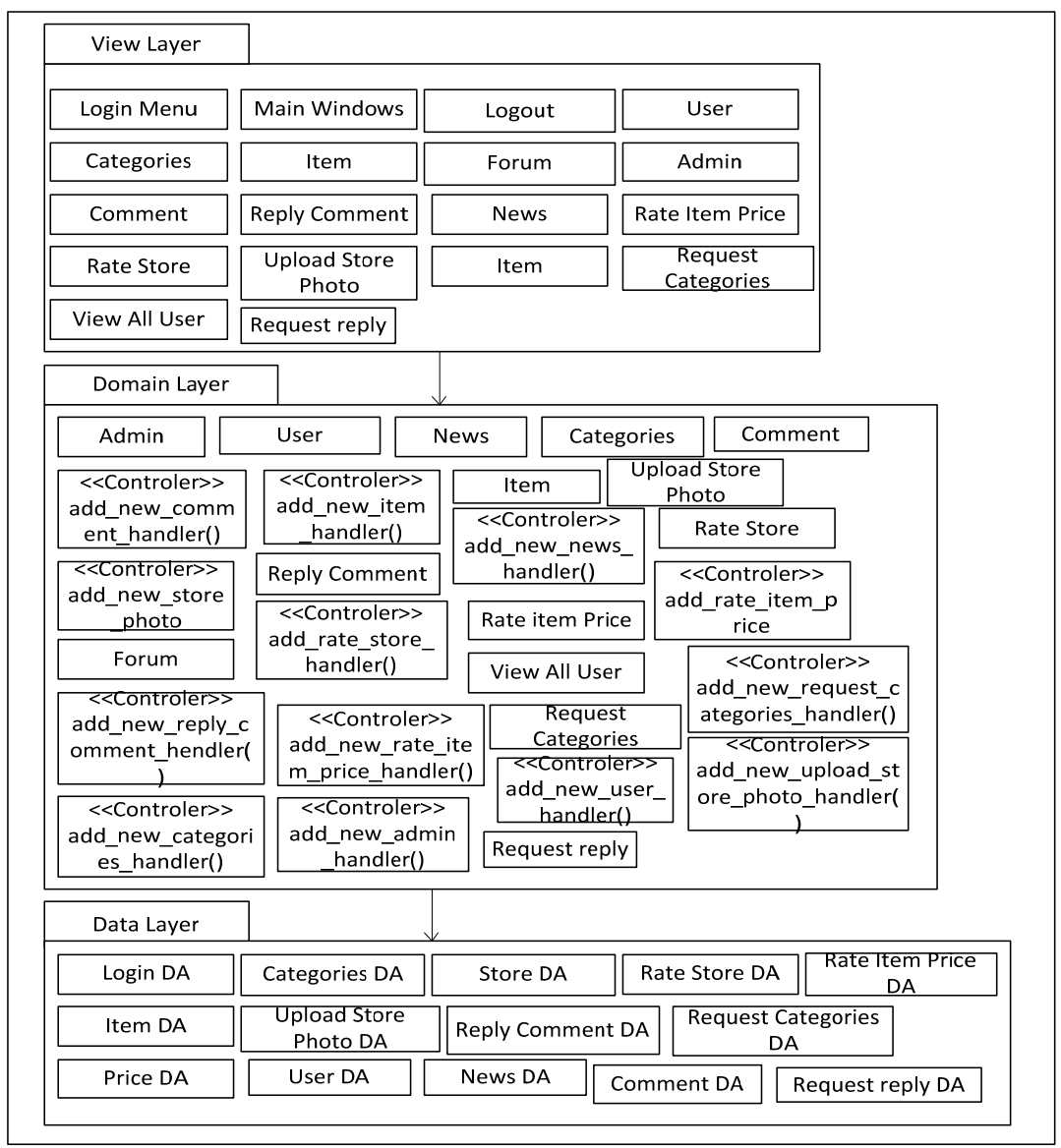

Gambar 9 Package Diagram

\section{Tampilan Layar Sistem}

Untuk tampilan layar sistem, Gambar 10 menunjukkan tampilan antarmuka pengguna: add or remove comment. Kemudian pada Gambar 11, tampilan antarmuka pengguna: add or remove reply.

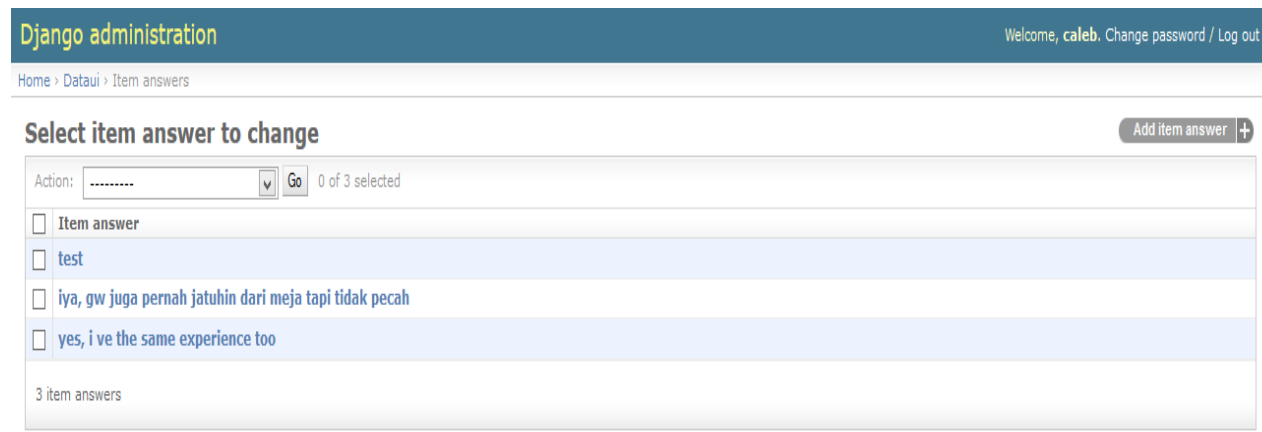

Gambar 10 User Interface: Add or Remove Comment 


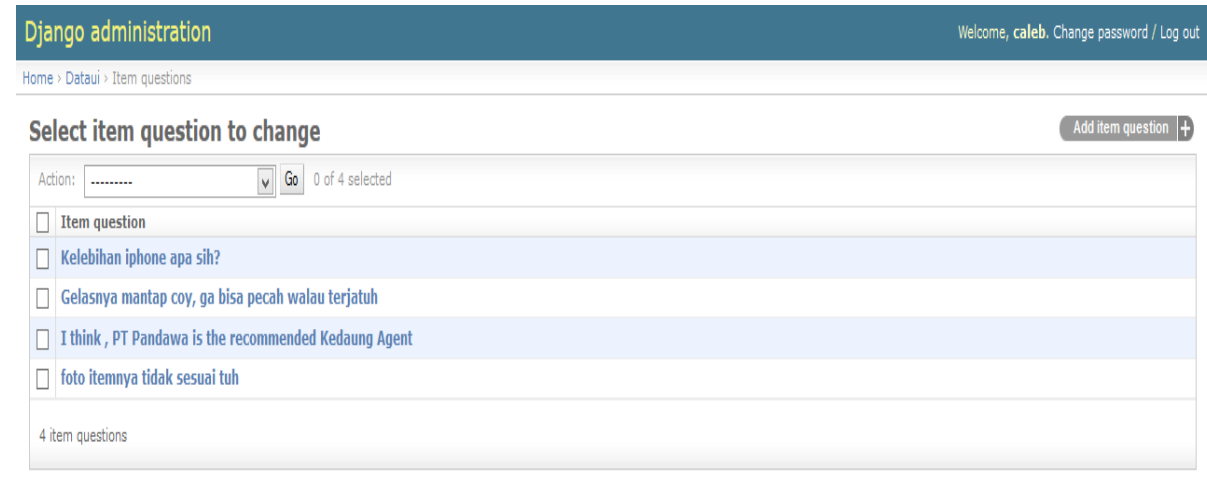

Gambar 11 User Interface: Add or Remove Reply

\section{SIMPULAN}

Berdasarkan penelitian disimpulkan beberapa hal. Pertama, PT Pandawa Maju Perkasa dapat memanfaatkan kekuatannya untuk merebut kesempatan yang ada. Strategi yang dapat diambil adalah membangun aplikasi website CKM yang berfungsi sebagai wadah untuk berbagi pengetahuan/informasi (knowledge sharing), forum yang dibagi berdasarkan kategori agar memudahkan customer untuk menulis komentar yang berfungsi sebagai media pertukaran knowledge, sekaligus dapat mempublikasikan, mempromosikan dan merekomendasikan produk yang ada kepada khalayak luas. Kedua, aplikasi website CKM yang dibuat memiliki fungsi untuk mempermudah PT Pandawa Maju Perkasa dalam mengumpulkan product Information \& knowledge. Website juga dapat berfungsi untuk memberitakan news \& event kepada user ataupun customer, dapat dijadikan media bagi perusahaan untuk memberikan knowledge kepada customer berupa hal-hal yang dilakukan perusahaan dan event yang diadakan perusahaan dalam bentuk tulisan dan foto.

\section{DAFTAR PUSTAKA}

Dalkir, K. (2011). Knowledge management in Theory and Practice. Massachusetts: The MIT Press.

Nawawi, I. (2012). Manajemen pengetahuan. Indonesia: Ghalia Indonesia.

Ronald, M. (2007). Knowledge Management System: Information and Communication Technologies for Knowledge Management. New York: Springer.

Sabherwal, R., \& Becerra-Fernandez, I. (2010). Knowledge Management Systems and Processes. New York: M.E. Sharpe.

Sanayei, A., \& Sadidi, M. (2011). Investigation of Customer Knowledge Management (CKM) dimension: A survey research. International Journal of Business and Management, 6(11), 234-239.

Widayana, L. (2005). Knowledge Management: Meningkatkan daya saing bisnis. Malang: Bayumedia.

Wilde, S. (2011). Customer Knowledge Management - Improving Customer Relationship Through Knowledge Application. New York: Springer. 